\title{
Class in Yugoslav Socialism and in the Post-Yugoslav Societies: Toward a Bourdieuan Repositioning of the Issue (Part 2)
}

\author{
Inga TOMIĆ-KOLUDROVIĆ \\ Institute of Social Sciences Ivo Pilar - Regional Centre Split, Croatia \\ inga.tomic-koludrovic@pilar.hr \\ Mirko PETRIĆ \\ Department of Sociology, University of Zadar, Croatia \\ mpetric@unizd.hr
}

\begin{abstract}
This article attempts to outline what its authors see as a potentially productive methodological approach for studying the connection between the notion of class in socialist Yugoslavia and class-related developments in its successor countries. The first part of the text consists of an extended elaboration of the ideological and social theoretical conceptions of class during the socialist period in Yugoslavia (1945-1990). This elaboration puts forth an interpretation that diagnoses an implicit and hitherto little noted interpretive move from Marx's dual to Weber's multidimensional model in the pre-empirical explanations of class in $\mathrm{Yu}-$ goslav social theory. Following this, an account is given of the 1970s and 1980s class-centred empirical research in Yugoslavia, vacillating between Marxism and structural functionalism, and eventually aiming at an analytical reconciliation of the notions of class and stratum. In the second part of the article, a repositioning of the issue in terms of Bourdieu's class theory is discussed as a potential contribution to explaining many of the blind spots of the socialist theorizing of class. This part of the article also contains a brief commentary of class-related research in post-Yugoslav societies, i.e. in the period of post-socialist transition. With references made to empirical studies carried out in two post-Yugoslav countries (Serbia and Croatia), the authors conclude that the concepts of methodologically cross-fertilized Bourdieuan class theory prove to be useful in this context as well, and can serve as a potent interpretive span between the socialist and post-socialist social spaces.
\end{abstract}

Key words: class, Yugoslav socialism, post-Yugoslav societies, Bourdieu's class theory, historical sociology 


\section{From Marx to Weber to Bourdieu?}

Before proceeding to the discussion of the theoretical model that we think could be useful in attempts to provide a cogent account of the mentioned "parallel stratifications" of Yugoslav socialist society, it needs to be pointed out that the material quoted in the central part of this article stems mostly from the final - academically most liberal - decade of existence of socialist Yugoslavia. In other words, the explanations of class-related issues presented in the preceding three sections of the article can be seen as a fruit of "a long period of gradual liberation from ideological limitations or fallacies imposed by politics on Yugoslav sociology" (Vuković, 1990: 17).

However, paradoxically, this does not make the analysis of these materials any easier. On the contrary, it could even be argued that it is easier nowadays to understand the texts from the periods of socialist Yugoslavia, which were academically less liberal and in which the results of empirical work were not present at all. Namely, in the case of the highly ideologically or theoretically charged texts from the early socialist periods, one can at least reasonably easily follow the general line of thinking of the ruling elite. In contrast, the analysis of both theoretical and empirical materials from the late-socialist period is complicated by the gradual rhetorical normalization of the official "self-management" terminology in the life world of Yugoslav socialism, ${ }^{1}$ making compari-

\footnotetext{
${ }^{1}$ What contributed to this rhetorical normalization in non-ideological terms was certainly the upward mobility brought about by the advancement of the process of industrialization, and experienced in the initial period of socialism by a large part of the population. Under the new conditions, former agrarian society members were brought into an urban context, where they were given industrial, office and military work, and frequently also obtained a right to live in "socially-owned" apartments. Many of these socialist citizens had a chance to advance during their lifetime to the living conditions that would be described in the class stratified societies as characteristic of the various strata of the "middle class". What is more, their initial upward mobility was, even in the subsequent periods of increasing "closure" of society, followed by the generous services of the welfare state that had also developed in the process. Bearing all this in mind, the upwardly mobile socialist citizens could be expected to have perceived their stratification position in terms not fitting into class designations used in the modern capitalist societies. The results of what little empirical research exists on the topic (all carried out in the late socialist period) seem to corroborate this expectation. Namely, in empirical studies quoted by Golubović (1988: 303-304), all the "peasants" and $60 \%$ of "workers" identify with such descriptions of their "class position", while there is much more variety of identifications in the more privileged strata of the population, some of whose self-identifications would certainly be perceived as odd in a non-socialist stratification context. By way of example, $1 / 5$ of the members of the elite socialist functionaries described themselves as "workers", as did 1/5 of office workers and intellectuals.
} 
sons with class designations used in the capitalist pluralist societies difficult. $^{2}$

One good illustration of the difficulties of theoretical analysis of class in Yugoslavia in the 1970s and 1980s is the predicament that arose when the dominant Marxist approach was faced with the task of interpretation of the "re-emergence of class" in the socialist context. While it was relatively easy to account for the element of "social" ownership of the means of production in abstract terms, there were problems as soon as one tried to account for its effect on stratification. Namely, what went under the rubric of "socially-owned" property in the socialist system was in actuality used

\footnotetext{
2 This is true even for comparisons with capitalist societies in the post-World War II period, which have - as is well known and widely argued - witnessed a certain "class decomposition" (Pakulski, 2001: 149) in relation to the pre-World War II social realities. The process that was diagnosed as early as 1950s by Schelsky (1965 [1953]), Dahrendorf (1957) and Nisbet (1959) only gained momentum in the subsequent decades, resulting in a key trend of "fragmentation of stratification" (Clark and Lipset, 1991: 408). It is also important to note, together with Giddens (1975 [1973]: 56), that the current diversifications in the structure of post-capitalist societies were implied by the twin processes of the decomposition of both the capitalist and the working class. Nevertheless, in the societies that were class structured for longer periods of time and did not experience revolutionary changes, the notion of class has remained different to the present day from that in the societies with less pronounced class trajectories. In these, so to call "class-conscious" societies, there are still reflections of the fact that social class was at some point "an understood reality", or in other words that "people took class for granted and knew in intimate and daily detail what the content and attributes were of the classes referred to" Nisbet (1959: 11). In contrast to that, the survey quoted by Golubovic (1988) clearly shows that the classification perceptions of the surveys (i.e. "subjective class") were in important aspects not comparable to classifications found in the capitalist pluralist societies. Although Golubović claimed that "social groups recognize[d] [their place] quite well, classifying themselves in the majority of cases into the appropriate class" (Golubović, 1988: 303) and suggesting their "realistic approach", it cannot go unmentioned that the surveyed elites quoted in her text described the society in question as "classless" or "one class", while other "strata" perceived the social differentiation in terms of the conflict between the "working class" and "counterclass" (variously described as "bureaucracy", "office workers/intelligentsia", "bourgeois" or "the rich"). When it comes to the difficulties of lifestyle research, which was for the first time brought to attention by Pešić (1977), they are comparable to that of class analysis. While there were no detailed visual analyses of lifestyle in late socialism, retrospective analysis of the photographs of young people from the period suggests that the second generation of city dwellers, socialized in the conditions of self-managing socialism, was increasingly hard to distinguish in cultural taste and general visual appearance from the declassed second generation members of the pre-socialist middle classes. This was a consequence of the work of the Yugoslav socialist system, ideologically espousing egalitarian values, providing free education and very accessible amenities of urban cultural and sports life. Young people who were the beneficiaries of this system formed the backbone of what Golubović classified as the socialist "new middle class".
} 
by individuals or contributed to their assets in a way that would be recognized as "private property" in a capitalist context. ${ }^{3}$

The reality of this situation gave rise to the mentioned complexifications of previously exclusively Marxist analyses, which were achieved by means of introduction of Weberian elements of class definition (as in the mentioned cases of Kuvačić and Popović), resulting in what could perhaps be described as "modestly multidimensional models". In the later period, in order to avoid potential class antagonism between the emerging privileged groups and industrial workers, the notions of "stratum" was introduced (also in the work of Popović and collaborators), but it was used interchangeably and on an equal footing with class (i.e. inconsistently) within the framework of the same analysis. Finally, there were also attempts to make some classification distinctions based on the "content" of work (as in Lazić's case) or by introducing the elements of "professional differentiation" (as suggested by Golubović).

But if these complexifications could even be partly successful in the attempts to resolve the problems stemming both from the choice of theoretical model and the character of social reality it was applied to, the question of (limited) mobility within the brackets the late- socialist society, ${ }^{4}$ simply could not be resolved by means of applying the explanation of the classical theorists (Marx, implicitly also Weber and Durkheim) upon which the socialist social theory relied.

Our contention here is that the repositioning of the issue in such a way that it is approached from the viewpoint of a model utilizing Bourdieu's

\footnotetext{
${ }^{3}$ One prominent example of the tacit approval of appropriation of "socially-owned property" for private gain was the institution of the "socially-owned apartment", i.e. one in which the "tenants" had a "right to live", could not be evicted from and could be inherited by their descendants. Other examples include the appropriation of essentially proprietary rights by the politically backed managerial elites or various benefits of the political elites themselves, also based on allegedly "socially-owned" properties.

${ }^{4}$ The limited mobility within the class or stratum brackets of the late-socialist society was at least partly based on what Lazić described as "individual accumulation of capitals". This possibility, it could be argued, was consistent with the "hybrid" nature of Yugoslav late-socialism, which was described in the already quoted Golubović's estimate as a combination of "etatism" and "limited 'market' socialism" (Golubović, 1988: 325). In such a context, (limited) mobility based on the individual accumulation of capitals obviously related to the "market" element of the society in question. The limitation of mobility, on the other hand, coincided with the "etatistic" element mentioned by Golubović, finding expression in the decisions of the nomenclature. These decisions were based on the presumption that, in terms of early Eco's semiotic theory, "[i]deology is the final connotation of the totality of connotations of the sign or of the context of the signs" (Eco, 1989 [1968]): 96). In other words, limits to mobility were determined by the limits of fidelity to the ruling ideology.
} 
concepts of habitus, capitals and social field, could be useful not only to help account for the mentioned upward mobility that took place within the brackets of late-socialist society, as described by Lazić, but also to understand the specificities of the Yugoslav model of socialism in general. Namely, Bourdieu's theoretical model and its components not only help us to diagnose the existence of "classes" (in the way Lazić or Golubović have done), but also to understand how social differentiation was generated in this particular context.

\section{Social differentiation in the socialist context: "political capital" in an expanded "political field"}

Based on empirical evidence of social mobility within the "class of mediators", presented in Lazić (1987), it is easy to conclude that it depended partly on educational attainment and partly on social connections of an upwardly mobile member of that "class".

The resources that this "agent" (to use Bourdieu's term) had at disposal translate well into Bourdieuan classification of capitals: connections derived from a possible party membership and/or communist family background can be viewed as indicators of "social capital", attained educational level is obviously an important constituent of "cultural capital", and "economic capital" could be relatively easily discerned from one's professional status.

However, the "ceiling" of one's upward mobility within the "class of mediators", and even more so the conditions for possible climbing into the elite class of "collective owners", depended on the possession (or not) of yet another capital. This was the capital that Bourdieu (1998b: 30) - in his lecture on the German Democratic Republic (GDR) - described as specific for the "Soviet version" of socialism and labelled as "political capital".

According to Bourdieu (1998b: 31), this capital was the basic principle of social differentiation in the context of GDR socialism. In the GDR, the only rivals that the members of the nomenclature had in the political field were the owners of educational capital, whose family background was partly also related to the nomenclature but who later criticized it from the intellectual viewpoint of wanting more "real" socialism.

Although certain resemblances to this situation can doubtless be found in any real-socialist context, ${ }^{5}$ Bourdieu (1998b) urged us to find specific in-

\footnotetext{
${ }^{5}$ In socialist Yugoslavia, examples of this obviously include the 1968 student protests in Belgrade and civil society movements in Slovenia in the 1980s.
} 
dicators, characteristic for the society to which we would like to direct our analytical attention. In the case of the late- socialist society in Yugoslavia, we argue that the specificity of the system can be best described by highlighting another concept central to Bourdieuan analysis: that of the "field".

In Bourdieuan theory, as is well known, the concept of the field is important because the autonomous fields out of which the social space is composed define relations between various positions that can be taken in the distribution of resources. In the context of Soviet-like socialist systems, according to the quoted Bourdieu's lecture, "political capital" and "political field" assumed a special relevance. While this was certainly also true of the late- Yugoslav socialist system - theoretically described by the ruling elite as "integral self-management" - it could be said in Bourdieuan terms that its specificity was in the attempt to expand the "political field" onto the entirety of the social space, co-opting all the citizens and virtually eliminating what remained of the autonomy of other fields, as defined in modern capitalist societies.

In effect, such a statement corresponds to Puhovski's already quoted conclusion according to which the entirety of social life in the late-socialist Yugoslavia appeared to be "politically produced" (Puhovski, 1990: 38). But a Bourdieuan description allows us further analysis: in spite of the totalizing tendencies of the "integral self-management" system, ${ }^{6}$ the conceptualization of different quasi-autonomous or at best partly autonomous fields in which the "insiders" with appropriate party and family background occupied privileged positions - but nevertheless needed to additionally "position" themselves - makes it possible to take note of power struggles in which agents did engage different capitals, but only following an initial political struggle qualifying them to mobilize resources in the first place.

Attempts to analyse that kind of "qualifying struggles", as well as subsequent mobilizations of specific compositions of different capitals that agents had at disposal, would - at least in theory - enable insights into social realities of the period going beyond the sweeping ideological generalizations of the ruling elite. Likewise, they would offer a possibility to go beyond the valuable but incomplete insights provided by the socialist theoreticians of

\footnotetext{
${ }^{6}$ The totalizing tendencies inherent to the late phase of the "self-managing" system are mentioned and described both in Lazić's 1980s (i.e. contemporaneous) analysis of class relations in Yugoslav socialism (Lazić, 1987), and in the retrospective analyses presented in his later masterly synthesis of class relations in pre-socialist, socialist and post-socialist Serbia (Lazić, 2011).
} 
class and by what little existed of empirical research of that topic in the latesocialist period. ${ }^{7}$ In other words, the approach we advocate would potentially open up a new perspective on how specific "distinctions" affecting stratification hierarchies were formed in the late-socialist period in Yugoslavia. ${ }^{8}$

${ }^{7}$ It should be stressed that the designation of the insights of the socialist theoreticians of class as "incomplete" should by no means be interpreted as an under-valuation of their contribution. On the contrary, in this article, social science texts from the socialist period are obviously the primary source for understanding the complexities and difficulties of class analysis in the socialist context. Namely, the discursive construction of these texts and self-fashioned solutions of their authors to methodological predicaments imposed equally by the dominant (Marxist) ideology and by the nature of the studied material, offer us important and otherwise hardly accessible insights into the social realities of "what could be understood as class" (Pavasović Trošt, 2012: 2) in socialist Yugoslavia. It is certainly useful in this context to remind oneself of Nagel's position, according to which "[u] nsolvable problems are not for that reason unreal" and his view that "[i]n that case such insight as we can achieve depends on maintaining a strong grasp of the problem instead of abandoning it, and coming to understand the failure of each new attempt at a solution, and of earlier attempts" (Nagel, 1979: xii). If "[t]hat is why we study the works of philosophers [...] whose views are accepted by no one" (Nagel, 1979: xii), we should also do the same in the case of social scientists. Likewise, it is perhaps useful to remark that even Rorty (1982: xxxi), from his pragmatist point of view, concedes that "you will not understand a certain period in the history of Europe unless you can get some idea of what it was like to be preoccupied by such questions", e.g. "you won't understand the West unless you understand what it was like to be bothered by the kinds of issues which bothered Plato". Again, the same is certainly true of the works of social scientists.

${ }^{8}$ It should be explained here why we think that a Bourdieuan approach to class analysis in socialism could be applied especially successfully to the objects of research from the late-socialist period. Namely, if we start from Hegel's dictum according to which philosophy (i.e. "theory") is "its own time apprehended in thoughts" (Hegel, 1952 [1820]: 11), it can be understood why we think that it is not by chance that Bourdieu's approach finds a special resonance in the analysis of the social realities roughly contemporaneous with the time when his theory was launched and gained initial prominence. For example, speaking of what could be described as a special subgroup of the socialist "new middle class" (Golubović) or "class of mediators" (Lazić) that took up politically engaged roles in cultural life, one immediately notices resemblances with Bourdieu's description of the "monopoly of the professionals" in French politics who possessed "material and cultural instruments necessary for active participation in politics", these being "notably free time and cultural capital" (Bourdieu, 1981: 4). The same goes for the recruiting mechanism, described by Bourdieu (2013 [2001]: 108-109) as working well in both the Church and Communist Party context, in which young people with modest social background are lifted to higher social positions by these institutions. In return, they owe them absolute loyalty, as their social status is completely dependent on the Church or Party. Finally, as Bourdieu claimed (2013 [2001]: 108) the "rules of entry" become ever-more regulated by the political parties, as the whole political field becomes increasingly bureaucratised. (The difference, in the case of socialist Yugoslavia, was of course that the "rules of entry" were not prescribed by different parties, but only by the one political party that was legal in that context - that is, by the League of Communists.) 
That such distinctions existed in the socialist context, in spite of the ideologically proclaimed "classlessness", is further evidenced by means of the application of the concept of "habitus", referring in Bourdieu's interpretation to incorporated traits of class membership ranging from bodily posture to mental schemata (the latter being made "palpable" in various expressions of one's "way of thinking”).

Assessments based on the application of Bourdieu's "practical sense" were obviously made on a daily basis in the socialist context as well, if for nothing else to distinguish between those who could be defined as "insiders" of and "outsiders" to the system. If such assessments could be made based on the equivalents of Bourdieuan incorporated "class traits", this would go to say that specific "distinctions" existed in the social space, regardless how one defined the stratification "brackets" to which they related.

What is more, since habitus reveals to a trained eye (either of a "regular" member of a society or an expert) the components of the "capitals" it is composed of, it potentially enables a sophisticated analysis of the stratification positions and general social contexts in which its various traits were acquired. In this respect, it is worth noting that Bourdieu's theory of the habitus as "a system of schemes of perception and appreciation of practices, cognitive and evaluative structures" insists on its being "acquired through the lasting experience of a social position" (Bourdieu, 1989: 19). This in turn would go to say that, due to the longevity and durability of habitus traits, certain conclusions about the socialist past could also be drawn based on the empirical analysis of the post-socialist social realities, in which the bearers of habituses formed in the socialist period are still present and could be researched by means of both quantitative and qualitative analysis. If, on the other hand, we would like to perform a retrospective analysis of habituses in the socialist period, the choice of methods is obviously restricted to document analysis, which also includes recent approaches and techniques developed within visual sociology. ${ }^{9}$

\footnotetext{
${ }^{9}$ Some of the analytical instruments needed for this task are discussed in a collection devoted specifically to visuality and politics after Bourdieu (Bismarck, Kaufmann and Wuggening, 2008). However, it should also be remarked that visual sociology has developed a number of other procedures and techniques in the recent period that could be utilized in the suggested analysis. It can therefore be said with a great deal of certainty that retrospectively performed visual analysis, combined with the analytical tools of historical sociology, would prove fruitful in the analysis of various habituses as instruments of social differentiation in the socialist period.
} 


\section{The difficulties and possibilities of Bourdieuan class analysis in post-socialism}

In a collection devoted to the discussion of the applicability of Bourdieu's theory to stratification issues in a post-socialist context, Ivana Spasić (2006: 168) first stated that this theory could be useful in the analysis of many aspects of contemporary Serbian society, but then concluded that it "[could not] help [in] finding a theoretical foundation for a deliberation of a polarized collision between different dimensions of social stratification, which exist in parallel and struggle for (legitimate) domination, with a highly uncertain result".

In contrast with this, we think that analyses based on a Bourdieuan approach can be of great help in the task for which Spasić sees it as unfit. More precisely, we hold it that a Bourdieuan repositioning of the analysis of class in socialism, which we suggested in the preceding section of this article, can help us to understand not only the socialist roots but also the current state of the "chaotic conglomerate of value scales and positions according to which the subjects can exercise choices" (Spasić, 2006: 167) in the anomic context of Serbian and other - partly differently "chaotic"10 - post-Yugoslav societies.

However, before outlining the elements of our proposal on how to put Bourdieuan class analysis to work in the post-socialist context, one should first further discuss the difficulties that such an analysis encounters

${ }_{10}$ The results of the multiple correspondence analysis Cvetičanin and Popovikj (2013) have carried out in four "Western Balkan" societies (Serbia, Bosnia-Herzegovina, Macedonia and Kosovo) indicate that configurations of social spaces (and, consequently, the homologies indicative of Bourdieuan "objective" or "theoretical class") in these societies follow largely different patterns. This insight must come as surprising to the analysts who have tended to view socialist Yugoslavia as a sort of "national container", roughly comparable to other such "national containers", i.e. neglecting the pronounced diversity (ethnic, social, religious) of its former constituent parts. Present-day analyses, such as that presented in the quoted paper (Cvetičanin and Popovikj, 2013), seem to reveal increasingly different "path dependencies" of the former Yugoslav republics and autonomous provinces. This would arguably be even more visible had the analysis performed by Cvetičanin and Popovikj also included the former northern republics of socialist Yugoslavia (Slovenia and Croatia). However, starting from the premise that "[g]iven the high complexity of the region, [Central East European] countries should never be lumped together" (Romano, 2014: x), one should also bear in mind that not only "generative structures" (to say it in Bourdieuan terms) in these countries are historically different, but also that "differences between Central East European countries are becoming more significant as the transition process continues" (Romano, 2014: x). In other words, any social science analysis carried out in this context - and particularly that of class - requires special analytical sensitivity and interpretive complexity. 
by necessity in post-Yugoslav societies. Although we challenge her general conclusion, in the brief discussion that follows we will actually start from Spasić's quoted text (Spasić, 2006), as the difficulties in question were initially well diagnosed within it.

Based on the qualitative analysis carried out in the middle of the first decade of the 21st century in Serbia, Spasic (2006: 166) concluded that in that social context there was no "legitimate culture" comparable to that described in the French case by Bourdieu as "common to all" and enabling "the production of a common, meaningful world, a common-sense world" (Bourdieu, 1984 [1979]: 468). According to Spasić, such an absence of "legitimate culture" in her empirical material was indicated by the already mentioned "problematic character" of the basic scale of values.

Furthermore, summing up the results of qualitative research carried out in 2011, Spasić (2012: 579) concluded that her subjects' judgments were predominantly based on "individual, psychological and subjective criteria", rather than on "the main lines of division between social groups" recorded in previous (international) studies of classification, which were of "sociological nature" and were based on "material status, education, ethnicity, social origin, urbanity/rurality etc." 11

In our view, in addition to diagnosing the absence of structural class identifications in present-day Serbia, Spasić's quoted insight should also be related to the social trajectories of her subjects, i.e. to the changes of the total scope and compositions of the capitals at their disposal, as well as to changes in their "sense of place" in their social context over time. This is certainly necessary if we want to approach the subject matter from a Bourdieuan perspective of the social world as "accumulated history"

\footnotetext{
${ }^{11}$ It is interesting to note that, although Spasić (2012) mentions some of the constituents of social class in the quoted passage (in her illustration of "lines of division" that had crystallized in previous research on the topic), she does not mention the umbrella term of "social class" itself. Examples much more drastic than this can be noticed in all post-Yugoslav societies, and can perhaps be described as instances of what Dolenec (2012) referred to as "structural blindness to questions of social class" in the post-socialist context. A piece of anecdotal evidence reported by Ilić (2012) is perhaps more eye-opening in this regard than even detailed sociological analyses devoted to this topic and based on qualitative research, such as the quoted Spasić's ones (Spasić, 2006, 2012), or Spasić's and Birešev's research specifically devoted to the topic of social classification (Spasić and Birešev, 2012). According to Ilić (2012: 19), "Michael Apple, the famous professor of education, a leftist and Marxist, came to Belgrade and held a lecture at the University of Belgrade. He introduced the term 'class' and nobody knew what he was talking about. The students were unable to ask a question, they did not know what to do with the concept of class, because they do not know what that is."
} 
(Bourdieu, 1986 [1983]: 241) or of the habitus seen as "the past which survives in the present" (Bourdieu, 1977 [1972]: 81).

In other words, we suggest that the post-socialist social realities should be approached from an analytical perspective that also takes into account the social realities of the preceding socialist period. We believe that such an approach would help us to gain a more profound understanding of both the socialist and post-socialist spaces in different "national containers", as well as to understand the nature of the connection between them in more general (i.e. "generalizable") terms.

Starting from the example at hand, and based on our analysis of the socialist theorizing of class contained in Part 1 of this article, we think it is justified to conclude that the absence of structural class identifications in the empirical material analyzed by Spasić (2006) can be at least partly attributed to the consistent and sustained ideological attempts to "dissolve" class relations in the preceding (socialist) period. ${ }^{12}$ In consequence of such attempts, as has already been explained, self-perceptions of the social status of the citizens of socialist Yugoslavia ${ }^{13}$ were largely inconsistent with those

\footnotetext{
${ }^{12}$ To be sure, in spite of the general ideological drift toward class "dissolution", the consequences of such attempts cannot be said to have been uniform in different parts of the former socialist Yugoslavia. Namely, due to historical reasons, the "generative structures" related to both pre-socialist class relations and their socialist afterlife differed in the different republics and autonomous provinces of Yugoslavia, as well as in some of their regions. Consequently, the forms and manifestations of the process of the attempted class "dissolution" varied considerably in these different social contexts. The differences in question are in themselves a worthwhile object of study and their detailed analysis - in addition to understanding pre-socialist and socialist social realities - would also help us to understand better the "dissolved" subjective class relations in post-Yugoslav societies. Nevertheless, in spite of the absence of such a comparative analysis so far, there can be little doubt that the consequences of the attempts to "dissolve" class identities in the socialist period had their share in the establishment of anomic relations in post-socialist Serbia described by Spasić in her article (Spasić, 2006).

${ }^{13}$ We use the term "citizens of Yugoslavia" instead of the term "Yugoslavs" for the sake of precision, i.e. to avoid mistaken connotations of a potentially assumed overarching and rather automatic supra-ethnic identity in the former Yugoslavia. Namely, as Sekulic, Massey and Hodson concluded after an elaborate analysis, "[o]nly a relatively small proportion of people in the former Yugoslavia ever expressed the social identity of being Yugoslavs" (Sekulic, Massey and Hodson, 1994: 95). Without engaging in a detailed analysis of the complexities of self-identification in different parts of socialist Yugoslavia, we consider it safe to use in this context a technical designation such as "citizens of socialist Yugoslavia". In this article, it is used as a common denominator for those experiencing the general ideological drift toward "dissolving" class relations in different regional and sub-regional "containers" of the republics and autonomous provinces of the country.
} 
used in the capitalist pluralist societies, no matter how "decomposed" the latter also proved to be in the post-World War II period.

Nevertheless, we hope that our analysis so far has already indicated that the insights of late socialist theorists of class, such as Mrkšić (1987), Lazić (1987) and Golubović (1988), can be reinterpreted in a Bourdieuan fashion, based on the explanation of the character of power struggles in the "quasi-autonomous" or at best "partly autonomous" fields of the socialist social space. Having said this, however, one should introduce a further difficulty for any analysis of class relations in socialist Yugoslavia, but also for the analysis of the same topic in the social spaces of post-Yugoslav countries. This difficulty arises when the temporal dimension is included into discussion.

With regard to that dimension, one should be reminded of the fact that the citizens of socialist Yugoslavia, throughout its existence, were simply not in position to experience a lasting membership of class defined outside of the limits set by the terminology of the ruling elite. Instead, they were exposed to the lasting attempts at the deconstruction of class, aimed -in the late socialist period - at dissolving even the initially legitimate and desirable working class identities into the "classlessness" of the "self-managing" "working people". That is why the cognitive aspects of habituses of the socialist "middle class", emerging in the described context, simply cannot be seen as fully equivalent to those of their counterparts in the non-socialist context: namely, they implied "a sense of one's place" and "a sense of the place of others" (Bourdieu, 1989: 19) in a very different way.

In other words, what was described by Golubović (1988) as a "middle class" in the late socialist context, referred in actuality to a social group that was positioned in a place that would elsewhere be labelled as "middle class" but did not possess a fully comparable "subjective" class identity. ${ }^{14}$ In consequence, some traits of a generalized "middle class" habitus (especially those "cognitive" ones) could simply not develop in the context of socialist Yugoslavia. This, in turn, means that - due to the mentioned longevity and durability of these traits - they have necessarily carried over from the socialist into the post-socialist social spaces, contributing to the

\footnotetext{
${ }^{14}$ We have seen, in part 1 of this article, that socialist social theorists referred to this "middle" position in the stratification of socialist society as that of "bureaucracy", "counterclass", "middle strata", and "mediating class". Even the rare explicit usages of the term, such as that by Golubović (1988), were actually pejorative.
} 
anomic character of class-relations in the present-day Serbian society described by Spasić (2006).

As has already been hinted at, the constellation ${ }^{15}$ described by Spasić (2006) represents yet another difficulty for the attempted analyses of class relations in both socialist and post-socialist social spaces. At the same time, however, this difficulty can also be seen as a new opportunity for researching the connectedness of these spaces. Such an opportunity seems all the more relevant in the light of the fact that the consequences of the mentioned transference of habitus traits across different social spaces can be seen as important not only in stratification-related discussions, but also for the interpretation of other changes taking place in these spaces.

By way of example, summing up the legacy of Bourdieu's Distinction (1979) for cultural sociology, Moebius (2009: 131-132) concluded that one of its lessons had been that modern capitalist class societies were not easy to transform by means of a will to change (revolution) or through rational decisions. According to Moebius, the stability in question was due exactly to the habitus-related force of inertia.

In contrast with this, it is well known that drastic and far-reaching changes took place within a very short period of time in all the post-socialist societies. Bearing Moebius's conclusion in mind, this can be taken to indicate that social space in these societies was constructed "according to different principles of vision and division" (Bourdieu, 1989: 19) from those at work in the capitalist class context.

Such different principles of construction of the socialist social space could even be said to have been confirmed by the course of events taking place in late-socialist Yugoslavia and - subsequently - in post-Yugoslav countries. Namely, if - to continue quoting Bourdieu - "it is true that, in advanced societies, economic and cultural factors have the greatest power of differentiation, the fact remains that the potency of economic and social differences is never so great that one cannot organize agents on the basis of other principles of division - ethnic, religious, or national ones, for instance" (Bourdieu, 1989: 19).

Given the nature of the developments that marked the last decade of existence of the socialist system in the former Yugoslavia, it is easy to

\footnotetext{
${ }^{15}$ The term "constellation" is here used in the way Heilbron (1995 [1990]: 10) used it to describe a specific and historically variable intellectual field "consisting of people who compete with one another for intellectual authority".
} 
see that it was exactly the latter set of principles of division quoted by Bourdieu (ethnic, religious, national) - taken individually or in combination - that had a prominent role in the conflicts marking the end of socialism in Yugoslavia and the subsequent establishment of a new post-socialist order. The mentioned principles also continued to exercise the role of key markers of division long into the post-socialist period, combined with other, primarily economic and consumption markers.

Finally, to make things even more complicated, since the operation of the habitus "expresses the social position in which it was elaborated" (Bourdieu, 1989: 19), there can be no doubt that both the "system of schemes of production of practices" and the "system of perception and appreciation of practices" formed in socialism were in some aspects losing relevance in the post-socialist context. Differently put, social, cultural and economic capitals acquired in the socialist context could in some aspects no longer be successfully applied in the emerging fields of the post-socialist social space. ${ }^{16}$

In Bourdieuan analysis, the degree of "inefficiency" in this respect which can be said to have helped produce "transition losers" - can be tied to the degree of change of the previously "quasi" or "partly autonomous" fields of the socialist social space. The more these fields changed in the direction of (capitalist) "autonomous" fields described in Bourdieu's work, the more "inefficiencies" and "mismatches" occurred in the classification struggles to those agents stuck in the "cognitive" aspects of their socialist habituses. ${ }^{17}$

\footnotetext{
${ }^{16}$ Such a failure to adapt to modified field conditions, taking place in the contexts of disjunction between subjective dispositions and objective conditions (Bourdieu, 1990: 108), is referred to in Bourdieuan theory as the "hysteresis effect". With regard to the longevity and durability of the habitus traits, mentioned earlier in this text, one should also remark here that Bourdieu considered the habitus to be "durable, but not eternal" (Bourdieu and Wacquant, 1992: 133). In other words, some of the habitus traits can erode or adapt to the new field conditions, thus making the analysis of individual instances of the "hysteresis effect" even more demanding. What is more, one should bear in mind that the inertial aspects of the habituses acquired in the socialist period could be different (i.e. characterized by less resistance to change) to those acquired in the context of modern capitalist class societies that are mentioned by Moebius (2009). Needless to say, this makes the analysis of the "hysteresis effect" in the anomic post-socialist context even more challenging.

${ }^{17}$ Some of the "inefficiencies" in the classification struggles taking place in the postsocialist context can be illustrated by the "moralizing" aspects of the statements of interviewees included in the empirical material quoted by Spasic (2006). The introduction of these aspects can be convincingly interpreted as one of the consequences of a mismatch
} 
An opposite example, indicating either the erosion or a complete lack or further transference of parental capitals and habitus traits acquired in socialism, can be found in the empirical research of youth lifestyles ${ }^{18}$ in post-socialist Croatia. Namely, a comparison of the results of research on that topic carried out in the late 1990s and in the second decade of the $21 \mathrm{st}$ century suggests that there occurred a certain lapse in the latter of the two periods into a "new classlessness", or more precisely "lifestyle-lessness", among contemporary Croatian youth. ${ }^{19}$ Taking into account empirical find-

between the capitals acquired in socialism and new configurations of the fields emerging in the post-socialist context. Namely, the socialist equivalents of "middle class" acquired significant cultural capital by means of accessible education, but their economic capital was partly indistinctly delineated due to the then-dominant egalitarian ideology. By way of example, significant individual material possessions of the citizens of socialist Yugoslavia were obscured by a terminology in which "socially-owned apartments" and various other effectively individualized privileges were not expressed in monetary terms. In the post-socialist context, these social actors ("agents" in Bourdieu's terminology), found themselves positioned in the fields in which their accumulated cultural and social capitals were largely irrelevant, and economic capital began to be explicitly related to personalized monetary and material possessions. The self-perception of the social position of these "transition losers", can be said to be in line with the general expectation that "[t]hose who feel to experience upward mobility are [...] less threatened by inequalities, while inequalities are more threatening for those who feel to experience less mobility or downward mobility" (Róbert 1999: 115). The moralizing aspects of the discourse of Spasić's interviewees can therefore be easily related to the self-perceptions described by Róbert (1999), although their rhetorical form obviously expresses the specificities of social constellations and trajectories in the post-Yugoslav context of Serbian society.

${ }^{18}$ Lifestyle research is obviously pertinent for a Bourdieuan analysis centred on capitals and habituses, since Bourdieu described lifestyles as "the systematic products of habitus, which [...] become sign systems that are socially qualified (as 'distinguished', 'vulgar', etc.)" (Bourdieu, 1984: 172). Furthermore, in the context of the subject matter dealt with in this article, capitals and habitus-centred lifestyle research can also be seen as a potential interpretive span between the socialist and post-socialist spaces. Namely, in a context in which traditional socio-economic factors appeared to have lost importance, lifestyles not only became an important indicator of social differentiation in post-industrial capitalist societies but also gained some importance in the context of late-socialist Yugoslavia. Therefore, studying lifestyles in a post-socialist context always establishes a certain relation to the preceding socialist context, i.e. to the capitals and habituses carried over from it into the subsequent period.

${ }^{19}$ The findings of youth lifestyle research carried out in Croatia at the end of the first decade of "post-socialist transition", as interpreted in Tomić-Koludrović and Leburić (2001), indicated that these lifestyles did not correspond to the types that had crystallized in the empirical research carried out in Western Europe in the 1980s and 1990s. They contained certain elements of Western European youth lifestyles (primarily in leisure activities and cultural taste), but mixed them in an atypical way. On top of that, the dominant identity orientations differed significantly from those found in the West. However, the fact remains 
ings indicating that in previous generations different lifestyle markers had succeeded in providing a certain "distinction" to their bearers, such a development seems to be due to the fact that parental capitals and habitus traits acquired in late-socialism ${ }^{20}$ have not managed to exercise the "force of inertia" characterizing habituses acquired in the context of modern capitalist class societies. In other words, in this case we also seem to be witnessing the consequences of a process related in some way to the attempted "dissolution of class" in the socialist period.

that these lifestyles did serve as an indicator of social differentiation and that they obviously came about as a result of some choices made, however limited these might have appeared from the perspective of the more elaborate (and more consumption-oriented) Western lifestyle differentiations. In contrast with this, the preliminary results of a survey carried out in the late post-socialist period (Tomić-Koludrović, Zdravković and Skočić, 2011) suggest that an overlap exists now with the characteristics of lifestyles found in the West, but only with those that characterize conventional lifestyles connected with lower strata (Tomić-Koludrović, Zdravković and Petrić, 2012). Some elements of cultural differentiation found in the previous survey do not seem to be present anymore and previously more pronounced optative choices of lifestyle markers appear to have been largely replaced by a homogenized taste mediated by the entertainment industry. Such findings were confirmed by the results of a subsequent larger survey, carried out by Zdravković (2014). What we have in mind when we refer to the "new classlessness" emerging in late post-socialism is a situation in which certain habitus traits and lifestyle markers have lost the relevance they previously had as cultural codes "secur[ing] profits of distinction" (Bourdieu, 1984: 3).

${ }^{20}$ Unfortunately, there exist no studies of lifestyles in the socialist period that could provide a ready basis for comparison with the results of the studies carried out in the postsocialist period. In the context of social science in late-socialist Yugoslavia, the notion of lifestyle was first taken up by Pešić (1977). Following the speedy publication of the translation (Hebdidge, 1980) of Hebdidge's book Subculture: The Meaning of Style (Hebdidge, 1979) in Yugoslavia, during the 1980s the issue of style was associated primarily with the notion of youth subcultures. Such a preoccupation found sociological expression later on in an overview of youth subcultural styles in Croatia from the 1970s to the 1990s, published only in the post-socialist period (Perasović, 2001). The first systematic elaboration of lifestyle as an analytical tool in empirical research of social differentiation was also presented only in the post-socialist period, in the studies written by Tomić-Koludrović and Leburić (2002). Likewise, the results of a first comprehensive empirical study of youth lifestyles (in post-socialist Croatia) were interpreted in Tomić-Koludrović and Leburić (2001). Based on the comprehensive post-socialist and rather sketchy socialist research of the topic, it would still be possible to draw certain tentative parallels and differences between latesocialist and post-socialist youth lifestyles. However, the formulation of more substantial arguments in this regard would certainly require additional historical sociological research of the socialist period. In spite of that, it seems safe to conclude that the analyses of lifestyles in the post-socialist period also carry some relevance for the discussion of socialist stratification. This is so because youth lifestyles in the post-socialist period are obviously related to the dispositions transferred by the parents socialized in the late-socialist period. 
All of this brings us back to Spasić's already mentioned diagnosis of the lack of "consensual cultural legitimacy" (Spasić, 2006: 167) in postsocialist Serbian society and our contention that - unlike what Spasić says - anomic post-socialist social realities can be analyzed from a Bourdieuan perspective. Moreover, we have also claimed that topics related to what Spasić described as "a polarized collision between different dimensions of social stratification" (Spasić, 2006: 168) in the post-socialist context, can only be fully understood if social trajectories of the researched subjects are taken into account.

In sum, we are arguing for an analytical perspective that would be Bourdieuan and would at the same time take into account the class-related aspects of the studied subject matter connected with the social realities of the preceding socialist period. We hope that we have managed to illustrate the possibilities of such an approach in our brief treatment of the topics concerning the "chaotic conglomerate of value scales and positions" (Spasić, 2006: 167) in contemporary (post-socialist) Serbia and the "new classlessness" of Croatian youth lifestyles in the late post-socialist period. The question now is how to proceed or, rather, what methodological instruments to use in order to reach new levels of Bourdieuan-inspired class analysis in the post-socialist context.

\section{Putting Bourdieu to work for class analysis in the post- socialist context}

In his review of Eyal, Szelényi, and Townsley's (1998) early attempt to apply Bourdieuan analysis to post-socialist societies, Burawoy concedes that their appropriation of "Bourdieu's framework of strategies around convertible capitals does indeed capture something about post-Soviet society" (Burawoy, 2001: 1113). However, according to this critic, there are limits to the quoted authors' deployment of Bourdieu's theory as "an all-purpose tool kit for the analysis of resources (capital), dispositions (habitus), and strategic action (in social space and fields)" (Burawoy, 2001: 1103).

In Burawoy's opinion, "it is a mistake to project this back into the past", that is, "to impose an asset-based theory on a position-based society". Furthermore, he is of the opinion that " $[b] \mathrm{y}$ universalizing Bourdieu's theoretical categories, Eyal et al. miss [their] historical and critical import and thereby elide profound differences between Soviet and post-Soviet orders" (Burawoy, 2001: 1113). 
While Burawoy's criticism is certainly worthy of further discussion, ${ }^{21}$ in the context of this article it is interesting to note that - in the issue of applicability - it essentially runs counter to what Spasić (2006: 168) says about the possibilities of a Bourdieuan-inspired class analysis in contemporary (post-socialist) Serbia. Namely, Burawoy (2001: 1013) takes the view that "Bourdieu's framework of strategies around convertible capitals" cannot be applied in a retrospective analysis of positionbased socialist societies. Spasić, on the other side, is of the opinion that Bourdieuan analysis cannot provide instruments to account for a "chaotic conglomerate of value scales and positions" (Spasić, 2006: 167) and "a polarized collision between different dimensions of social stratification" (Spasić, 2006: 168) that, according to her, characterize present-day Serbian society. ${ }^{22}$

Although these two authors come to their conclusions for different reasons and with different social contexts in mind, the arguments they develop share the same starting point: they can be said to rest on the belief that there exist contemporary (modern) societies in which a Bourdieuan class analysis cannot be adequately performed. This is obviously considered as due to the specificities of these societies and their differences from the historical "national container" (i.e. the French society of the 1960s and 1970s) in which the instruments were formulated that make up - to use Burawoy's expression - "the now-familiar tool kit of Pierre Bourdieu" (Burawoy, 2001: 1011).

\footnotetext{
${ }^{21}$ In brief, Burawoy criticizes the lack of a critical and political dimension in Eyal, Szelényi, and Townsley's (1998) development of what they see as a dynamic comparativehistorical theory, capable of accounting for social change in the post-socialist context. In spite of the ambition of the authors to engage in the discussion of "comparative capitalisms", Burawoy holds the view that capitalism actually "drops out of picture" in their work: this is due to an underestimation of the importance of capital accumulation, class relations of domination and exploitation, as well as of global forces that are currently prominent. Burawoy is also critical of the authors' "path" perspective on transition, extending in some cases all the way back to the pre-communist days of Hungary, Poland and the Czech Republic but focused on "trajectory adjustment" of elite individuals rather than on institutional transformation. What is especially important in the context of this article is Burawoy's further criticism of methodological aspects of the reviewed book, to which we will return later on in the text.

${ }^{22}$ For the sake of clarity, one should say that - unlike Burawoy - in the quoted text Spasić (2006) does not deal at all with the possibilities of application of a Bourdiean approach to the socialist past. Her discussion is limited to the context of post-socialist Serbian society.
} 
Such an argument is not new ${ }^{23}$ and can be said to have been effectively removed not only by well-formulated theoretical counter-arguments ${ }^{24}$ but also by a large and ever-increasing number of Bourdieu-inspired empirical studies carried out in highly diverse social contexts. ${ }^{25}$ While the current approaches to "culturalist class analysis", inspired largely by Bourdieu's

\begin{abstract}
${ }^{23}$ What comes to mind first in this regard is the reception of Bourdieu's work in the United States of America. Following the seminal review of Bourdieu's and Passeron's work by DiMaggio (1979), and even some attempts of the same author to put the reviewed approach into practice in the American context (e.g. DiMaggio and Useem, 1978; DiMaggio, 1982), as well as the noted Brubaker's essay (1985), there followed a less enthusiastic reception phase noticing "a number of theoretical ambiguities and gaps in the original model, as well as specific methodological problems" and aiming at "decouple[ing] cultural capital from the French context in which it was originally conceived to take into consideration the distinctive features of American culture" (Lamont and Lareau, 1988: 153). Although the usefulness of Bourdieu's theory for explaining how social reproduction works in the United States has been challenged by a number of influential scholars (for review cf. Holt, 1997), this phase can be said to have culminated in the publication of Lamont's (1992) account of the differences in the formation and reproduction of the French and American uppermiddle classes. The quoted Holt's article that attempted to "recover Bourdieu's theory of taste from his critics" (Holt, 1997) represented a turn of the tide in looking at the problem and offered methodological solutions important for the development of contemporary approaches to Bourdieuan-inspired analysis of cultural practices and social reproduction. Although the discussion on the development of Bourdieu's reception in the United States has by no means been finished (cf. e.g. Lamont, 2012a; Lizardo, 2012; Mische, 2012; Lamont, 2012b), Lamont's 2012 essay announces in its title that Bourdieu has been "good to think with" also in the U.S.-American context. For an interesting account of this subject matter by a scholar positioned between two cultures (French and U.S.-American) cf. also Wacquant (1993).

${ }^{24}$ The quoted Holt's (1997) article is a relevant illustration of such well-formulated theoretical and methodological arguments.
\end{abstract}

${ }^{25}$ As Santoro (2008: 2) explained in the introduction to a symposium devoted to explaining Bourdieu's insertion in the "global field", an even provisional bibliography of translations and empirical research inspired by Bourdieu's work would be very long. Although Santoro also states that the applicability and usefulness of Bourdieu's sociological categories has been widely discussed "even by sympathetic scholars", he lists the instances of Bourdieuan-inspired research in the United States of America, United Kingdom, Australia, Germany, the Netherlands, Denmark, Finland, Norway, Canada, Israel, Central European post-communist countries, Spain, Brazil and various countries in Latin America, China, Japan, Haiti, India and Laos. According to Sapiro (2013), the transferability in space and time of Bourdieu's analytical model is possible due to its relational nature. The authors goes on to explain in Bourdieu's (1998a [1994]: 6) terms that it is because of such relational nature that comparisons (and by implication transfers of the model) are "possible only from system to system". It is also worth noting that, according to Sapiro (2012), Bourdieu began to reflect on the transferability of his model already in 1989, faced with different re-appropriations of his work outside of the French context. This also required certain adjustments of his theory. 
work, ${ }^{26}$ have indeed tended to drift away "from the conventional concerns of class analysis with property and market relations towards an emphasis on the multiple forms of capital" (Flemmen, 2013: 325), as well as from "fundamental social relationships - of exploitation, domination and closure", discussed in Marxian and Weberian theory alike (Flemmen, 2013: 336), this still does not mean that it is not possible to develop a reworked, multidimensional approach to class analysis "that benefits from the power of Bourdieu's ideas while retaining a perspective on the fundamentals of class relations in capitalism" (Flemmen, 2013: 325).

Even if such an approach would be limited to the analysis of "differentials of power that are generic to capitalism" (Flemmen, 2013: 337) (i.e. if it would indeed not be possible to apply fully the elements of a Bourdieuan analysis in a specific socialist or post-socialist social space, as Burawoy /2001/ and Spasić /2006/ claim), we would still hold the view that it would nevertheless be productive to reflect on these spaces from a Bourdieuan perspective. Namely, important insights about them can also be gained ex negativo, i.e. by establishing to what kind of analysis they do not lend themselves and why. ${ }^{27}$

Furthermore, one should also remark that a data analysis technique closely associated with the Bourdieuan approach (Multiple Correspondence

\footnotetext{
${ }^{26}$ Flemmen (2013: 325) quotes Diane Reay's 2011 remark that the "cultural turn" in class analysis in Great Britain has also at the same time been a Bourdieuan turn.

27 Paradoxically enough, Burawoy's and Spasić's explanations of why they think a Bourdieuan analysis is not applicable to the social spaces they describe can actually serve, nevertheless, as an illustration of the potential usefulness of reflecting on these societies from a Bourdieuan perspective. Namely, their explanations have in effect further substantiated their insights or hypotheses on the nature of socialism as a "positionbased" society (Burawoy, 2001: 1113) and on the lack of "consensual cultural legitimacy" in post-socialist Serbian society (Spasić, 2006: 167). Bourdieu's lecture on the German Democratic Republic that we have quoted earlier (Bourdieu, 1998b) has certainly contributed to our knowledge of the "Soviet version" of socialism and we hope that the same has been the case with our comments on certain aspects of late Yugoslav socialism, made from a Bourdieuan-inspired perspective. It should also be noted that Burawoy, in illustrating one of the techniques he considers suitable to studying the historical continuities at work in post-socialist societies ("revisiting anthropological studies of socialism"), and referring to his own ethnographic work in Hungary, concludes that the "habituses" of his subjects "[s]haped under late communism, [...] had indeed endured the transition" (Burawoy, 2001: 1115). Needless to say, such a use of the term "habitus" by Burawoy represents an unintended confirmation of the fact that at least some instruments and notions from the Bourdieuan "tool kit" can be used retrospectively to analyze socialist society.
} 
Analysis $)^{28}$ has already been successfully applied in the research of the social spaces in several post-Yugoslav countries (including Serbia), and that it has yielded highly interesting results, conducive to further research. ${ }^{29}$ The same goes for the instances of "cultural class analysis" that have been performed in post-socialist Serbia and Slovenia. ${ }^{30}$

Bearing this in mind, the question would not seem to be whether Bourdieuan approaches are applicable in the social spaces of post-Yugoslav countries. Rather, the question should be: how to formulate a Bourdieuan approach to analysis that would be suited to the specific socio-historical context in which these societies find themselves? And further, given the obvious importance of historical continuities for perspective of the social world as "accumulated history" (Bourdieu, 1986 [1983]: 241): how methodologically to connect the socialist and post-socialist spaces, i.e. how to study the individual and collective trajectories extending over these two spaces?

To begin with, one should say that a Bourdieuan approach suited to the analysis of post-socialist social spaces would necessarily encounter all the difficulties experienced by similar approaches in contemporary social contexts with different collective trajectories. The current key issue of Bourdieuan analysis in "advanced capitalist societies" - i.e. in the societies

${ }^{28}$ As is well-known, Multiple Correspondence Analysis (MCA) has been developed and refined by the students of the French statistician Jean-Paul Benzécri. For an account of Bourdieu's long-standing personal involvement in a programme of quantification and formalization cf. Lebaron (2009). According to Lebaron (2009: 12), Bourdieu often referred in the 1960s "to the need for scientific instruments which would be capable of grasping the relational dimension of social reality". At the end of the 1960s, he turned to the results of Benzécri's school around Correspondence Analysis (CA), finding in it an approach that was mostly in "elective affinities" with his own theory. Lebaron (2009: 11) underlines that Bourdieu's interest in this matter was not "an arbitrary result of historical contingencies", but a "logical consequence of a critical experience and reflection about the shortcomings of dominant quantitative approaches in social sciences". This critical reflection led Bourdieu to "a conscious and systematic move toward a geometric frame-model more adapted to his conception of the social world". As is well known, following the application of correspondence analysis in Bourdieu's Distinction (1979), it has become one of the hallmarks of his general approach to empirical research.

${ }^{29}$ The results of this research were initially presented in Cvetičanin and Popovikj (2013).

${ }^{30}$ In Serbia, the analyses of this kind (Cvetičanin, Nedeljković and Krstić, 2011, 2012) have been carried out with mapping intentions and based on a Bourdieuan correspondence analysis approach, which makes their results suitable for comparison and their methodologies open to further development. Empirical research in Slovenia (Luthar and Kurdija, 2011; Luthar et al., 2011) has paid particular attention to media consumption in the attempt to interpret "cultural stratification" in that country. 
with longer uninterrupted periods of "differentials of power that are generic to capitalism" (Flemmen, 2013: 337) - is certainly how to integrate into the predominant "cultural class analysis" the notion of the "relations of power and domination founded in the economic institutions of capitalism" and how to account for this notion "as a crucial element of what class is" (Flemmen, 2013: 325).

However, the answers provided to these questions in the context of "advanced capitalist societies", e.g. those provided by the quoted author, ${ }^{31}$ will need to be discussed from a - so to speak - "site-specific" perspective and adapted or complemented by the empirical and theoretical researchers of post-socialist societies. An approach that would do justice to the complexities of the issue of power in the post-socialist context should - among other things - also take into account the attempts to explain the specificities of the relationship between class and power in the socialist period. ${ }^{32}$ The research of present-day (post-socialist) power relations in the context of class, on the other side, would arguably profit most from various forms of qualitative research, especially since the results of such research could also be triangulated with the results of the quantitatively based social space analyses already in progress. ${ }^{33}$

${ }^{31}$ Flemmen (2013) refers to the problems of what he considers to be two types of contemporary class analysis closely associated with Bourdieu's sociological theory and methodology (he labels them as the social space approach -SSA and the field-analytical approach - FAA). According to him, the main problem they share is their "neglect, or dismissal, of a concept of class tied to production and markets" (Flemmen, 2013: 336). The author then proposes four steps that he considers necessary for a "reworked class analysis" that would be able to integrate important elements of the mentioned Bourdieuan approaches (SAA and FAA) with the emphasis on capitalist economic relations he thinks are crucial for efficient class analysis in contemporary capitalist societies. According to him, such a "reworked class analysis" (1) "needs to recognize that property relations and the workings of capitalist markets generate significant differentials of power", (2) "needs to address how these property and market relations are shaping the distribution of income and wealth", (3) needs to connect these conceptions of class with the notions of field, forms of capital and with social space as a stratification structure", and (4) the latter connection "needs to respect the necessity of a non-reductionist, multidimensional approach to stratification" (Flemmen, 2013: 337).

${ }^{32}$ In addition to the literature outlined in Part 1 of this article, the researchers of the topic of power in class relations in the post-socialist period would be well-advised to consult works specifically devoted to the descriptions of power relations within the context of "Yugoslav industrial democracy" (most notably Županov, 1985 [1969]).

${ }^{33}$ Spasić's research mentioned in this article (Spasić, 2006, 2012) already indicates such potential for triangulation, as do various other examples of contemporary qualitative research carried out in Serbia. 
If they are to respond to the demands put before timely versions of Bourdieuan-inspired class analysis in the context of "advanced capitalist societies", similar attempts in the context of post-socialist societies should also be based on multidimensional approaches. Within such a framework, however, there exists ample space to develop innovative research strategies that could contribute to the advancement of this field of analysis in general. ${ }^{34}$

Finally, given the importance of class-related developments in the preceding socialist period for the analysis of class in post-socialist societies, there remains the question of how to analytically connect the socialist and post-socialist social spaces. This could be achieved by the application of a research category spanning the two spaces by being relatively unproblematic to operationalize in both of them.

The most likely candidate for this task is the category of lifestyle: namely, besides playing an important role in Bourdieu's class theory, that category - and exactly in the Bourdieuan interpretation of it as a carrier of manifestations of social class differences - can also be said to be of special importance for the analysis of class relations in socialism, especially in the late socialist period. ${ }^{35}$ Furthermore, it is not of little importance that there

\footnotetext{
${ }^{34}$ As an example of such an innovative research strategy, launched in the post-socialist context, one can quote the attempt to base social space analysis both on the data concerning practices and values of the survey respondents, i.e. the attempt to combine the elements of a distinctly Bourdieuan analysis (research of practices) with those more characteristic of Inglehart's theory of modernization (research of values). Such an approach has been applied in the questionnaire development for the project "Resistance to Socio-Economic Changes in Western Balkan Societies", coordinated by Predrag Cvetičanin and carried out in 2012 and 2013 in Bosnia- Herzegovina, Kosovo, Serbia and Macedonia. The first - promising - results of this project were presented in Cvetičanin and Popovikj (2013).

${ }^{35}$ Unlike what Spasić (2006) claims for the contemporary, post-socialist Serbia, it is clear that in Yugoslav socialism there existed an easily discernible "legitimate culture". However, in this largely "position-based society" (to quote the expression from Burawoy, 2001: 1113), even in its final, economically most liberal phase, the "individual accumulation of capitals" was restricted, as we know from Lazić (1987), and the elements of the capitalist class stratification were at best present as "potentials obstructed in their development" (Mrkšić, 1987: 4). It is small wonder that in such circumstances the notion of lifestyle gained in importance, especially in what Mrkšić (1987) refers to as the "middle strata", as well as in a part of the "elitist stratum". In a context in which some of the markers of class statuses in the capitalist societies could not come to expression, pronounced cultural and lifestyle differences served as their logical substitutes. Having said this, however, one should also be reminded of the fact that the increased prominence of lifestyle and cultural differences in late-socialist Yugoslavia essentially coincided with a similar trend in the "advanced capitalist societies". As Clark and Lipset
} 
exists -as we have already indicated - a certain body of lifestyle research in the post-socialist period that can serve as an orientation in comparative studies and a basis for further refinement of lifestyle research strategies. Such a refinement is already in process ${ }^{36}$ and indicates once again that the category of lifestyle is suitable for the intended use because it proves among its other qualities - to be open to cross-fertilization.

Another strategy that could be of help in the task of analytically connecting the socialist and post-socialist social spaces is the one suggested by Burawoy (2001) in his criticism of Eyal, Szelényi and Townsley's (1998) attempt to apply Bourdieuan analysis to post-socialist societies. Burawoy initially criticizes "past-dependent" approaches, such as that of the quoted authors or Stark and Bruszt's (1998) whose book he also reviews. ${ }^{37}$

(1991: 52) remind us, the key trend in Western societies in the period in which lifestyles issues came to prominence in late-socialist Yugoslavia could be described as "fragmentation of stratification", which also included "the weakening of class stratification, especially as shown in distinct class-differentiated life-styles". According to the quoted authors, the same period was also characterized by "the decline of economic determinism and the increased importance of social and cultural factors". To illustrate some important differences that existed between the two social contexts ("advanced capitalist" and the Yugoslav socialist one) in spite of the trend of partial convergence, one could continue to quote Clark's and Lipset's elements of the "fragmentation of stratification" in the West. One would then realize that the element stating that "social mobility [was in the West beginning to be] less family determined [and] more ability and education determined" would not be fully applicable in the socialist context, as the classification by the decision-makers of one's family (or even one family member) as belonging to the circle of "outsiders" to the system meant an insurmountable obstacle to professional vertical mobility, unless the unfavourable family background was compensated for by "LC [League of Communists] membership" testifying to one's "moral-political aptitude". As Lazić (1987: 110) explained, "selection criteria" imposed by the "authoritarian social command structure" were even in late Yugoslav socialism still based on "conformism" and "loyalty" rather than on independent educational achievement. On the other hand, what Clark, Lipset and Rempel (1993) saw as the general reason for the weakening of class conflicts in the West (the rise of the welfare state), as well as the "structured heterogeneity within classes, which have been in evidence for decades" (Flemmen, 2014: 561), were also observable in the Yugoslav social context, bearing witness once again to the "hybrid" nature of the late-socialist system in that country.

${ }^{36}$ In Zdravković (2014), the analytical toolkit developed in Tomić-Koludrović and Leburić (2001) has been expanded by the introduction of the dimension of media practices, which is of high and increasing importance for the analysis of contemporary youth lifestyles, also in the post-socialist context.

37 The difference between Eyal, Szelényi and Townsley's (1998) and Stark and Bruszt's (1998) "past dependent" approaches is in that the former extends its analysis of individual "trajectory adjustments" as far back as the pre-communist past, while the latter starts its analysis at the moment of extrication from the state socialist past. 
In his outline of a possible "post-socialist theory", which would be critical and analogous in its political intentions to postcolonial theory, Burawoy proposes "to suspend the study of origins for the study of class relations in the present" (Burawoy, 2001: 1103). In other words, according to him, in order to study adequately the development and effects of "sui generis economic processes" at work in post-socialist societies, "one must subordinate the study of historical paths and trajectories to careful in situ analyses of actual social relations" (Burawoy, 2001: 1114).

Having said this, however, Burawoy goes on to quote the examples of "ethnographic research in post-Soviet societies that, instead of searching out the influence of origins, start out by examining constraints in the present". ${ }^{88}$ He concludes that it is shown in these works that "[p]olitical and economic relations, inherited from the past to be sure, govern the unfolding dynamics of property redistribution" but that in them "[t]he point of departure is the present, and it is from this vantage point that the past is understood" (Burawoy, 2001: 1114). In this way, as Burawoy had announced earlier, research in the post-socialist context would not only contribute to "a recovery of class" in present-day conditions, but would at the same time also represent "the excavation of embedded socialism" (Burawoy, 2001: 1103).

In spite of his criticism of Eyal, Szelényi, and Townsley's (1998) "reconstruction" of Bourdieu's theory, ${ }^{39}$ Burawoy's relation to the socialist past in the post-socialist present is fully compatible with the already men-

\footnotetext{
${ }^{38}$ The books Burawoy mentions as important examples in these regard are studies of decollectivization in Bulgaria (Verdery,1999; Creed, 1999), Zbierski-Salameh's (1999) field research in rural Poland, and Woodruff's (1999) observation of post-socialist enterprises in Russia. He also makes mention of the results of his own industrial ethnography of the 1980s (socialist) Hungary (Burawoy and Lukács, 1992), when proposing "revisiting anthropological studies of socialism" as a possible technique of before-and-after evaluations of the effects of transition processes.

${ }^{39}$ Eyal, Szelényi, and Townsley (1998: 187) indeed "claim to have reconstructed Bourdieu's theory, shifting it from a static explanation of social reproduction into a dynamic, comparative-historical theory which is able to explain social change". Burawoy, however, objects that they have "in the process sacrifice[d] the political dimension of Bourdieu's writings - the analysis of the reproduction and mystification of class relations" (Burawoy, 2001: 1103). He is equally critical of the authors attempt to "extend Weber's vision of different capitalisms as the project of different bourgeoisies and expand Weber's distinction between class and status (rank) to compare pre-communist, communist, and post-communist societies". According to Burawoy, in the process of adapting Weber's analytical framework, the authors have also lost "Weber's critical insights: his iron cage view of capitalism, his tying of capitalist efficiency to bureaucratic domination, and more generally his own disenchantment with Western rationalism" (Burawoy, 2001: 1102).
} 
tioned Bourdieuan perspectives of the social world as "accumulated history" (Bourdieu, 1986 [1983]: 241) and of the habitus as "the past which survives in the present" (Bourdieu, 1977 [1972]: 81). The question, again, is how to operationalize in empirical research the perspective on history the two authors obviously share.

One answer to this question has already been provided by Burawoy's invitation to researchers of post-socialism to engage in ethnographies of everyday life and uncover in them the traces of "embedded socialism". Another one, which would arguably produce equally interesting results, could be also administered quantitatively. Namely, if we start from Bourdieu's concession that complex and elusive concepts such as the "field" are not easy to follow in his relationalized, de-substantialized mode of thinking, we can also agree with the conclusion that the nature of data we work with as sociologists is such that the configurations of the field can only be discerned through the characteristics the carriers of which are concrete individuals. ${ }^{40}$ That, in turn, is why the mentioned concept of the field simply invites a historical, empirical approach: it needs to be thought through over and over again (Bourdieu and Wacquant, 1992: 110), in relation to the objective indicators at our disposal.

Bearing this in mind, it could be argued that some knowledge about the family trajectories of the surveyed respondents - and these are obviously in some way related to the current set of "objective indicators" they provide about themselves when surveyed - could be gathered by asking them to provide information on some indicators connected not only with their lives but also with the lives of their parents and grandparents. ${ }^{41}$ It

\footnotetext{
${ }^{40}$ The concept of field is important for the current discussions of class, as - in Bourdieu's later work - it completely replaced the terminology based on the notion of the "class", which was still present in some of his early writings. As Spasić (2004: 291-292) succinctly summarizes, Bourdieu abandoned class-related terminology because he felt it contributed to a substantialist worldview, in that it depicted a group of concrete individuals with a set of attributable characteristics. "Power" was in that context seen as a palpable characteristic transferred to the individuals in question by means of their belonging to the group. Instead, Bourdieu's concept of field emphasizes the structure of various forces at work in it, while "power" is conceptualized in the form of capitals.

${ }^{41}$ It is realistic to expect reliable information on the indicators concerning the lives of the preceding two generations. Namely, in most cases, the surveyed respondents have a direct knowledge of these family members (parents, grandparents). It should perhaps be mentioned here that in Elias's "figurational" or "process sociology", the length of association of two or three generations significantly contributes to the degree of group cohesion and power. As Dunning and Hughes (2013: 64) have stated, it is evident that "Elias was,
} 
goes without saying that it would be inappropriate to base any far-reaching conclusions about social spaces of the past on the basis of indicators gathered in this way, but they would certainly provide some background for a better understanding of the changes in individual trajectories of the surveyed. This is especially important in the post-socialist context, in which information on the socialist segment of social class trajectories is not easily available, ${ }^{42}$ and in which prominent theoreticians of the subject also experience problems in their attempts to account for the components and course of development of the "accumulated [class] histories" present in the current social world. ${ }^{43}$

\section{Concluding remarks: toward a Bourdieuan-inspired historical sociology of class}

It may at first glance seem paradoxical that we have concluded our discussion on the (future) possibilities of a Bourdieuan-inspired class analysis in

at least in part, developing his observations in response to long dominant conventional Marxist and Weberian formulations of power." Or, in the words of the author himself, simply the length of association can be considered sufficient to generate "the degree of group cohesion, the collective identifications, the commonality of norms, which are apt to introduce the gratifying euphoria that goes with the consciousness of belonging to a group of higher value and with the complementary contempt for other groups" (Elias and Scotson, 2008 [1965]: 4).

${ }^{42}$ This is - in addition to the atypical social realities of this period - due to the difficulties of sociological definition of class described in Part 1 of this article.

${ }^{43}$ This is, again, partly due to the difficulties of sociological definition of class in the socialist period, and partly to the choice of a neo-Marxist paradigm that cannot respond to certain requirements put before it in the contemporary sociological discussion of class. Aware of such shortcomings, in the theoretical discussion preceding his monumental historical-sociological account of class developments in Serbia over the past two centuries, Lazić (2011) recapitulates the problems encountered in contemporary class analysis by other prominent neo-Marxist theoreticians such as Wright (1997), considers Wallerstein's World Systems Theory as an interpretive framework for explaining the globalization-related aspects of contemporary class discussion, and sees even the classical Thompson's (1963) work on the English working class as a potential guidance in the attempts to describe the historical process of the "making of class" in other social contexts. (In this regard, it is perhaps interesting to note that William J. Sewell has in a relatively short period of time passed the way from criticizing Thompson's account of the "making of class" /Sewell, 1986/ to noticing the "transposability of schemas" /Sewell, 1992: 17/ to which social actors as defined by Bourdieu have access, and which "can be applied across a wide range of circumstances".) We hope that we have succeeded in this article at least to put up for consideration the elements of a Bourdieuan class-analysis as conducive to potentially stimulating interpretations of the different historical moments in the "accumulated histories" of class in different post-socialist social spaces. 
post-socialism by emphasizing the necessity to study the presence in it of the socialist past. In a way, we have come full circle from an account of the socialist theorizing of class - presented in Part 1 of this article - to the invocation of the need to study history in order to understand the present.

In connection with the topics relevant for understanding the social realities of post-Yugoslav - and in general post-socialist - countries, we are certainly neither the first nor the last proponents of such an approach. For instance, the central message of the already quoted book that has attempted to "explain Yugoslavia" to readers from other parts of the world (Allcock, 2000), could be summarized in the following way: "understanding Yugoslavia necessitates a study of the continuities in its development against the backdrop of the broader dynamics of modernity and globalisation" (Byford, 2003: 492).

Needless to say, the book in question has been written by a remarkable advocate of historical sociology as a method of inquiry: we wholeheartedly support its author's call for more historical sociological accounts of various aspects of his inexhaustible subject. Likewise, turning our attention to the current developments in the ever wider field of Bourdieu-inspired studies, we are happy to notice that the tenets and instruments of the approach to the study of society elaborated by Bourdieu are now no longer seen as suitable only in the context of exclusively "presentist" sociological studies deplored by Inglis (2014). They are also increasingly mentioned in the context of historical sociology (Steinmetz, 2011), and even in the context of historical analysis in the humanities as well, as a recent collection devoted to that topic indicates (Gorski, 2013a).

However, having said this, we would like to qualify further what we mean when we say that we argue for a Bourdieuan-inspired historical sociology of class. On one hand, this means that we are of the opinion that Bourdieu's general approach to the analysis of the social world, as well as the instruments developed during the long process of formulation of that approach, can serve as an important corrective and interpretational aid in the retrospective analysis of the socialist realities of class in the former Yugoslavia. That would be the perspective of what Inglis (2014: 102) refers to as "the sub-discipline called "historical sociology" and describes as "a particular and rather narrow genre, involving the use of sociological concepts and procedures to analyse a particular social context at a given point in time". 
On the other hand, we also - together with Inglis - see the need for a different kind of presence of historical consciousness in the wider disciplinary framework of sociology. We would also certainly argue for "a markedly more self-aware and historically-sensitive sociology" (Inglis, 2014: 99), placed outside of a narrowly defined sub-disciplinary genre understood in the meaning described above.

However, where we disagree with Inglis is in his placement of Bourdieu within the context of canonical "legitimator figures" who - according to him - "are at their weakest (or at least, most highly problematic) when making claims about the historical processes that they claim have led to the contemporary social condition" (Inglis, 2014: 104).

Admittedly, Inglis (2014: 115) concedes that Bourdieu - due to his intellectual biography and the nature of the French social scientific field "might be exonerated in large part" from the charges directed at other mentioned "legitimator figures" contributing to the widespread "presentism" in British sociology (Giddens, Beck, Bauman). Nevertheless, his placement of Bourdieu within the current "cannon formation" group in British sociology identified by Outhwaite (2009) obviously goes in the direction opposite to that taken by Gorski (2013b), who claims that Bourdieu has in effect been mistakenly treated as a reproduction theorist rather than as an analyst who was concerned with the (essentially historically framed) explanation of social change beyond the dualism of structure and event.

Bringing into the discussion the possibilities for Bourdieuan-inspired analyses in the post-socialist context, outlined in the present part of this article (Part 2), we would like to explain that we see the present and possible future applications of Bourdieu's "framework of strategies" (Burawoy, 2001: 1113) in post-Yugoslav countries as extremely important for the establishment of a much needed "social history of the present" (Calhoun, 2013) in these social contexts. Differently said, we hold the view that the result of these Bourdieuan-inspired analyses would help to create a solid empirical body of knowledge about a series of consecutive "presents" that - taken together - make up the social realities of the late post-socialist period.

By way of example, the results of the Bourdieuan-inspired mapping analyses performed so far in Serbia by the teams coordinated by Predrag Cvetičanin (Cvetičanin, 2007; Cvetičanin, Nedeljković and Krstić, 2011; Cvetičanin, Nedeljković and Krstić 2012; Cvetičanin and Popovikj, 
2013) have already provided the desired "sociological snapshots" of several consecutive "presents" of cultural practices in that country, based on which one can already make note of certain changes happening within a relatively short period of time. Even more importantly, the preliminary results of a mapping exercise carried out in several post-Yugoslav countries (Bosnia-Herzegovina, Kosovo, Macedonia, Serbia), and presented in Cvetičanin and Popovikj (2013), have provided mappings of the social spaces in these countries that run contrary to the stereotypical expectations of their uniformity due to their former belonging to the same "national container".

Further analysis of this data set will certainly contribute to a better understanding of the nature of the differences that have become evident in the (multidimensional) representations of the constructions of social spaces in the countries under study. It is, of course, already clear that not even very sophisticated interpretations can provide a definitive answer to the question whether the differences that have emerged are due more to historically different "generative structures" or to the contextual changes in the post-socialist period, engendering the processes by which the social structures and social realities of these societies seem to be becoming more distant from each other.

However, there is also no doubt that our provisional conclusions would be based on more verified data had such Bourdieuan-inspired mappings existed before, throughout different stages of the late-socialist and postsocialist periods. Based on such mappings, a very different general picture of the social changes in these countries in the late-socialist and postsocialist periods would have emerged from the current one, based largely on unidimensional perspectives and normative accounts characteristic of "transitology".

In the same way as the existence of the mentioned "sociological snapshots" of consecutive "presents" would certainly cumulatively contribute to the development of a "more self-aware and historically-sensitive" sociology that Inglis (2014: 99) calls for, so would the existence and the subsequent public dissemination of the accounts of social reality more complex from those usually found in policy papers contribute to creating a form of "historical consciousness", not only of the researchers but also of the researched. In this way, quite apart from the narrow disciplinary discussion of structuration, we see the possibilities of Bourdieuan-inspired research to 
contribute to a more widely shared understanding of the "historicity" of empirical research results and of sociology as "a historically situated form of knowledge production" (Inglis, 2014: 99).

Finally, while completely agreeing with Inglis (2014: 99) that "[a] sophisticated understanding of the contemporary world is made possible only by an equally sophisticated understanding of very long-term historical processes", we would like to emphasize the need also to develop and put into practice in the post-socialist context the research techniques and procedures typical of historical sociology in the sense of a narrow sub-disciplinary genre involving the use of a sociological perspective to analyze and interpret various social contexts at given points in the past.

Namely, as we hope to have succeeded in showing in this article - if by nothing else than by the lengthy footnotes needed to explain various aspects of everyday life and the political system in the now ever more distant socialist past - the insights gained through such narrowly conceived historical sociological research would be crucial in securing an understanding of the continuities of social class developments in the socialist and post-socialist contexts. As we have argued in this article, the Bourdieuaninspired research "tool kit" offers a number of instruments that could be used by the researchers embarking on this task.

In conclusion, however, we would like to return to the present and emphasize once again that we hold the view that only approaches based on multidimensionality and open to further cross-fertilization can adequately respond to the complexities required of contemporary class analysis in "advanced capitalist" and post-socialist societies alike. In this article, we hope to have offered convincing arguments for considering Bourdieu's sociological theory and Bourdieuan-inspired research as a flexible organizing framework able to meet such requirements. What is more, we also hope to have indicated that such an organizing framework would also be able to overcome the specific difficulties emerging in the analysis of the post-socialist afterlife of class realities of the "hybrid" Yugoslav socialist system. We are encouraged in this view by the quality of research results gained by the mentioned Bourdieuan-inspired mappings of social space carried out in several post-Yugoslav countries. What remains to be done now is to employ these and future empirical findings in interpretive efforts aimed at grappling with the difficult post-socialist realities of class. 


\section{REFERENCES}

Allcock, John B. (2000). Explaining Yugoslavia. London: Hurst.

Bismarck, Beatrice von, Kaufmann, Therese and Wuggening, Ulf (eds) (2008). Nach Bourdieu: Visualität, Kunst, Politik. Wien: Turia + Kant.

Bourdieu, Pierre (1977 [1972]). Outline of a Theory of Practice (translated by Richard Nice). Cambridge: Cambridge University Press.

Bourdieu, Pierre (1979). Distinction: critique sociale du jugement. Paris: Minuit.

Bourdieu, Pierre (1981). "La représentation politique. Éléments pour une théorie du champ politique", Actes de la recherche en sciences sociales, 36-37: 3-24.

Bourdieu, Pierre (1984 [1979]). Distinction: A Social Critique of the Judgement of Taste (translated by Richard Nice). Cambridge, Mass.: Harvard University Press.

Bourdieu, Pierre (1986 [1983]). "The Forms of Capital", in: John G. Richardson (ed.). Handbook of Theory and Research for the Sociology of Education. New York: Greenwood, pp. 241-258.

Bourdieu, Pierre (1989). "Social Space and Symbolic Power", Sociological Theory, 7 (1): 14-25. doi: 10.2307/202060

Bourdieu, Pierre (1990). In Other Words: Essays Towards a Reflexive Sociology (translated by Matthew Adamson). Stanford, Ca.: Stanford University Press.

Bourdieu, Pierre (1998a [1994]). Practical Reason: On the Theory of Action (translated by Randall Johnson). Cambridge: Polity.

Bourdieu, Pierre (1998b). "Die 'sowjetische' Variante und das politische Kapital", in: Praktische Vernunft: Zur Theorie des Handelns (translated by Hella Beister). Frankfurt am Main: Suhrkamp, pp. 28-32.

Bourdieu, Pierre (2013 [2001]). "Das politische Feld", in: Franz Schultheis and Stephen Egger (eds). Politik: Schriften zur Politischen Ökonomie. Berlin: Suhrkamp, pp. 97-112.

Bourdieu, Pierre and Wacquant, Loïc J. D. (1992). An Invitation to Reflexive Sociology. Chicago: University of Chicago Press.

Brubaker, Rogers (1985). "Rethinking Classical Theory: The Sociological Vision of Pierre Bourdieu", Theory and Society, 14 (6): 745-775.

Burawoy, Michael (2001). "Neoclassical Sociology: From the End of Communism to the End of Classes" (Review Symposium), American Journal of Sociology, 106 (4): 1099-1120. doi: 10.1086/320299

Burawoy, Michael and Lukács, János (1992). The Radiant Past. Chicago: University of Chicago Press.

Byford, Jovan (2003). [Untitled review of John B. Allcock's Understanding Yugoslavia], Europe-Asia Studies, 55 (3): 491-492.

Calhoun, Craig (2013). "For the Social History of the Present: Pierre Bourdieu as Historical Sociologist", in: Philip S. Gorski (ed.). Bourdieu and Historical Analysis. Durham, N.C.: Duke University Press, pp. 36-67.

Clark, Terry Nichols and Lipset, Seymour Martin (1991). "Are Social Classes Dying?”, International Sociology, 6 (4): 397-410. doi: 10.1177/026858091006004002 
Clark, Terry Nichols, Lipset, Seymour Martin and Rempel, Michael (1993). "The Declining Political Significance of Social Class", International Sociology, 8 (3): 293-316. doi: 10.1177/026858093008003003

Creed, Gerald (1999). "Deconstructing Socialism in Bulgaria", in: Michael Burawoy and Katherine Verdery (eds). Uncertain Transition: Ethnographies of Change in the Postsocialist World. Lanham, Md.: Rowman \& Littlefield, pp. 223-244.

Cvetičanin, Predrag (2007). Kulturne potrebe, navike $i$ ukusi građana Srbije $i$ Makedonije [Cultural needs, habits and tastes of the citizens of Serbia and Macedonia]. Niš: Odbor za građansku inicijativu.

Cvetičanin, Predrag, Nedeljković, Jasmina and Krstić, Nemanja (2011). "Constructing a Cultural Map of Serbia”, in: Predrag Cvetičanin and Ana Birešev (eds). Social and Cultural Capital in Western Balkan Societies. Belgrade: Centre for Empirical Cultural Studies of South-East Europe, The Institute for Philosophy and Social Theory of the University of Belgrade, pp. 181-209.

Cvetičanin, Predrag, Nedeljković, Jasmina and Krstić, Nemanja (2012). "The Cultural Map of Serbia or the Reconstruction of the Field of Cultural Practices in Serbia", in: Predrag Cvetičanin (ed.). Social and Cultural Capital in Serbia. Niš: Centre for Empirical Cultural Studies of South-East Europe, pp. 71-96.

Cvetičanin, Predrag and Popovikj, Misha (2013). "Who Likes the Change - Evaluation of Socio-Economic Changes in Western Balkan Societies", paper presented at the conference Lost in Transition - Citizens' Engagement with Transitional Changes in Western Balkans Societies, Skopje, Macedonia, 6 July 2013.

Dahrendorf, Ralf (1957). Soziale Klassen und Klassenkonflikt in der industriellen Gesellschaft. Stuttgart: Enke.

DiMaggio, Paul (1979). “On Pierre Bourdieu” (Review Essay), American Journal of Sociology, 84 (6): 1460-1474.

DiMaggio, Paul (1982). "Cultural Capital and School Success: The Impact of Status Culture Participation on the Grades of U.S. High School Students", American Sociological Review, 47 (2): 189-201. doi: 10.2307/2094962

DiMaggio, Paul and Useem, Michael (1978). "Social Class and Arts Consumption: The Origins and Consequences of Class Differences in Exposure to the Arts in America", Theory and Society, 5 (2), 141-161. doi: 10.1007/BF01702159

Dolenec, Daniela (2012). "Democratization, War and Inequality: Analysing the Persistence of Structural Blindness to Questions of Social Class in Croatia", paper presented at the conference Bringing Class Back In: The Dynamics of Social Change in (Post) Yugoslavia, Marija Bistrica, Croatia, 7 December 2012. Dunning, Eric and Hughes, Jason (2013). Norbert Elias and Modern Sociology: Knowledge, Interdependence, Power, Process. London: Bloomsbury.

Eco, Umberto (1989 [1968]). La struttura assente. Milano: Bompiani.

Elias, Norbert and Scotson, John. L (2008 [1965]). The Established and the Outsiders. Dublin: University College Dublin Press.

Eyal, Gil, Szelényi, Iván and Townsley, Eleanor (1998). Making Capitalism without Capitalists: The New Ruling Elites in Eastern Europe. London: Verso. 
Flemmen, Magne (2013). "Putting Bourdieu to Work for Class Analysis: Reflections on Some Recent Contributions", British Journal of Sociology, 64 (2); 325-343. doi: 10.1111/1468-4446.12020

Flemmen, Magne (2014). "The Politics of the Service Class: The Homology of Positions and Position-Takings", European Societies, 16 (4): 543-569. doi: 10.1080/14616696.2013.817597

Giddens, Anthony (1975 [1973]). The Class Structure of the Advanced Societies. New York: Harper \& Row.

Golubović, Zagorka (1988). Kriza identiteta savremenog jugoslovenskog društva: jugoslovenski put u socijalizam viđen iz različitih uglova [Identity crisis of the contemporary Yugoslav society: the Yugoslav way to socialism seen from different angles]. Beograd: Filip Višnjić.

Gorski, Philip S. (ed.) (2013a). Bourdieu and Historical Analysis. Durham, N.C.: Duke University Press.

Gorski, Philip S. (2013b). "Introduction: Bourdieu as a Theorist of Change", in: Philip S. Gorski (ed.). Bourdieu and Historical Analysis. Durham, N.C.: Duke University Press, pp. 1-15.

Hegel, Georg Wilhelm Friedrich (1952 [1820]). Philosophy of Right (translated by T. M. Knox). Oxford: Oxford University Press.

Hebdidge, Dick (1979). Subculture: The Meaning of Style. London: Methuen.

[Hebdidge, Dick] Hebdidž, Dik (1980 [1979]). Potkultura: značenje stila [Subculture: the meaning of style] (translated by David Albahari). Beograd: Rad.

Heilbron, Johan (1995 [1990]). The Rise of Social Theory (translated by Sheila Gogol). Cambridge: Polity.

Holt, Douglas B. (1997). "Distinction in America? Recovering Bourdieu's Theory of Tastes from its Critics", Poetics, 25 (2-3): 93-120. doi: 10.1016/S0304422X(97)00010-7

Ilić, Dejan (2012). "Postjugoslavenske kulture - koliko se razumijemo? Tribina Trećeg programa HR-a" [Post-Yugoslav cultures - how much do we understand each other? Croatian Radio's Third Programme Public discussion] (Transcript), http://www.hrt.hr/195438/analogna-i-digitalna-mreza-odasiljaca/tribina-treceg27-prosinca (27. 2. 2014).

Inglis, David (2014). "What is Worth Defending in Sociology Today? Presentism, Historical Vision and the Uses of Sociology", Cultural Sociology, 8 (1): 99-118. doi: 10.1177/1749975512473288

Lamont, Michèle (1992). Money, Morals and Manners: The Culture of the French and the American Upper-Middle Classes. Chicago: University of Chicago Press.

Lamont, Michèle (2012a). "How Has Bourdieu Been Good to Think With? The Case of the United States", Sociological Forum, 27 (1): 228-237. doi: 10.1111/j.1573-7861.2011.01309.x

Lamont, Michèle (2012b). "Generational Differences in Accounts of the Development of U.S. Cultural Sociology - Let Me Count the Ways: Response to Lizardo's and Mische's Comments”, Sociological Forum, 27 (1): 251-254. doi: 10.1111/j.1573-7861.2011.01312.x 
Lamont, Michèle and Lareau, Annette (1988). “Cultural Capital: Allusions, Gaps and Glissandos in Recent Theoretical Developments", Sociological Theory, 6 (2): 153-168. doi: 10.2307/202113

Lazić, Mladen (1987). U susret zatvorenom društvu? Klasna reprodukcija u socijalizmu [Toward a closed society? Class reproduction in socialism]. Zagreb: Naprijed.

Lazić, Mladen (2011). Čekajući kapitalizam: nastanak novih klasnih odnosa u Srbiji [Waiting for capitalism: the emergence of new class relations in Serbia]. Beograd: Službeni glasnik.

Lebaron, Frédéric (2009). "How Bourdieu 'Quantified' Bourdieu: The Geometric Modelling of Data", in: Karen Robson and Chris Sanders (eds). Quantifying Theory: Pierre Bourdieu [Dordrecht]: Springer, pp. 11-29.

Lizardo, Omar (2012). "The Three Phases of Bourdieu's U.S. Reception: Comment on Lamont", Sociological Forum, 27 (1): 238-244. doi: 10.1111/j.15737861.2011.01310.x

Luthar, Breda and Kurdija, Slavko (2011). "Razred in kulturne distinkcije" [Class and cultural distinctions], Teorija in praksa, 48 (4): 982-1003.

Luthar, Breda, Kurdija, Slavko, Jontes, Dejan, Malnar, Brina, Tivadar, Blanka, Kamin, Tanja and Oblak, Tanja (2011). "Medijska potrošnja, razred in kulturna stratifikacija: končno raziskovalno poročilo s sumarnikom" [Media consumption, class and cultural stratification: final research report with a summary]. Ljubljana: Fakulteta za družbene vede.

Mische, Ann (2102). "Bourdieu in Contention and Deliberation: Response to Lamont and Lizardo", Sociological Forum, 27 (1): 245-250. doi: 10.1111/j.15737861.2011.01311.x

Moebius, Stephan (2009). Kultur. Bielefeld: Transcript.

Mrkšić, Danilo (1987). Srednji slojevi u Jugoslaviji [The middle strata in Yugoslavia]. Beograd: Istraživačko-izdavački centar SSO Srbije.

Nagel, Thomas (1979). Mortal Questions. Cambridge: Cambridge University Press.

Nisbet, Robert A. (1959). "The Decline and Fall of Social Class", Pacific Sociological Review, 2 (1): 11-17. doi: 10.2307/1388331

Outhwaite, William (2009). "Canon Formation in Late 20th-Century British Sociology", Sociology, 43 (6): 1029-1045. doi: 10.1177/0038038509345696

Pakulski, Jan (2001). "Class Paradigm and Politics", in: Terry Nichols Clark and Seymour Martin Lipset (eds). The Breakdown of Class Politics: A Debate on Post-Industrial Stratification. Washington, D.C.: Woodrow Wilson Center Press, pp. 137-160.

Pavasović Trošt, Tamara (2012). "Social Class as a Predictor of Nationhood Worldviews? A Comparison of Narratives of Low- and High- SES Serbian and Croatian Youth", paper presented at the conference Bringing Class Back In: The Dynamics of Social Change in (Post) Yugoslavia, Marija Bistrica, Croatia, 7 December 2012.

Perasović, Benjamin (2001). Urbana plemena: sociologija subkultura u Hrvatskoj [Urban tribes: the sociology of subcultures in Croatia]. Zagreb: Hrvatska sveučilišna naklada. 
Pešić, Vesna (1977). "Društvena slojevitost i stil života" [Social stratification and lifestyle], in: Mihailo V. Popović, Silvano Bolčić, Vesna Pešić, Milosav Janićijević i Dragomir Pantić. Društvene nejednakosti: sociološko istraživanje u Beogradu [Social inequalities: a sociological survey in Belgrade]. Beograd: Centar za sociološka istraživanja, Institut društvenih nauka, pp. 121-196.

Puhovski, Žarko (1990). Socijalistička konstrukcija zbilje [Socialist construction of reality]. Zagreb: RS SOH and Školska knjiga.

Róbert, Péter (1999). "Perceived Mobility and Attitudes Toward Getting Ahead: An 'East-West' Comparison", in: Niko Toš, Peter Ph. Mohler and Brina Malnar (eds). Modern Society and Values: A Comparative Analysis Based on ISSP Project. Ljubljana: FSS, University of Ljubljana; Mannheim: ZUMA Mannheim, pp. 111-140.

Romano, Serena (2104). The Political and Social Construction of Poverty: Central and Eastern European Countries in Transition. Bristol: Policy Press.

Rorty, Richard (1982). Consequences of Pragmatism: Essays 1972-1980. Minneapolis: University of Minnesota Press.

Santoro, Marco (2008). "Putting Bourdieu in the Global Field: Introduction to the Symposium", Sociologica, 2 (2): 1-32 . doi: 10.2383/27719

Sapiro, Gisèle (2012). "Du théoricien social à l'intellectuel global: la réception internationale de l'œuvre de Pierre Bourdieu et ses effets en retour”, in: Frédéric Lebaron and Gérard Mauger (eds). Bourdieu. Paris: Ellipses, pp. 373-389.

Sapiro, Gisèle (2013). "La carrière internationale de La Distinction", in: Philippe Coulangeon and Julien Duval (eds). Trente ans après La Distinction de Pierre Bourdieu. Paris: Ellipses, pp. 45-58.

Schelsky, Helmut (1965 [1953]). "Die Bedeutung des Schichtungsbegriffes für die Analyse der gegenwärtigen deutschen Gesellschaft", in: Helmut Schelsky. Auf der Suche nach Wirklichkeit, Gesammelte Aufsätze zur Soziologie der Bundesrepublik. Düsseldorf and Köln: Eugen Diedrichs Verlag, pp. 331-336.

Sekulic, Dusko, Massey, Garth and Hodson, Randy (1994). "Who Were the Yugoslavs? Failed Sources of a Common Identity in the Former Yugoslavia", American Sociological Review, 59 (1): 83-97. doi: 10.2307/2096134

Sewell, William H., Jr. (1986). "How Classes are Made: Critical Reflections on E. P. Thompson's Theory of Working-Class Formation", http://deepblue.lib.umich. edu/bitstream/handle/2027.42/51104/336.pdf (27. 2. 2014).

Sewell, William H., Jr. (1992). "A Theory of Structure: Duality, Agency, and Transformation", American Journal of Sociology, 98 (1): 1-29.

Spasić, Ivana (2004). Sociologije svakodnevnog života [Sociologies of everyday life]. Beograd: Zavod za udžbenike i nastavna sredstva.

Spasić, Ivana (2006). "Distinkcija na domaći način: diskursi statusnog diferenciranja u današnjoj Srbiji” [Distinction, our way: discourses of status differentiation in Serbia today], in: Miloš Nemanjić and Ivana Spasić (eds). Nasleđe Pjera Burdijea: pouke i nadahnuća [The legacy of Pierre Bourdieu: lessons learned and inspirations]. Beograd: Institut za filozofiju i društvenu teoriju, Zavod za proučavanje kulturnog razvitka, pp. 137-170. 
Spasić, Ivana (2012). “Jugoslavija kao mesto normalnog života: sećanja običnih ljudi u Srbiji” [Yugoslavia as a place for living a normal life: memories of ordinary people in Serbia], Sociologija, 54 (4): 577-594. doi: 10.2298/SOC1204577S

Spasić, Ivana and Birešev, Ana (2012). "Social Classifications in Serbia Today between Morality and Politics", in: Predrag Cvetičanin (ed.). Social and Cultural Capital in Serbia. Niš: Centre for Empirical Cultural Studies of South-East Europe, pp. 155-174.

Stark, David and Bruszt, László (1998). Postsocialist Pathways: Transforming Politics and Property in East Central Europe. Cambridge: Cambridge University Press.

Steinmetz, George (2011). "Bourdieu, Historicity, and Historical Sociology", Cultural Sociology, 5 (1): 45-66. doi: 10.1177/1749975510389912

Thompson, E[dward] P[almer] (1963). The Making of the English Working Class. London: Victor Gollanz.

Tomić-Koludrović, Inga and Leburić, Anči (2001). Skeptična generacija: životni stilovi mladih u Hrvatskoj [The sceptical generation: youth lifestyles in Croatia]. Zagreb: AGM.

Tomić-Koludrović, Inga and Leburić, Anči (2002). Sociologija životnog stila: prema novoj metodološkoj strategiji [Sociology of lifestyle: towards a new methodological strategy]. Zagreb: Naklada Jesenski i Turk and Hrvatsko sociološko društvo.

Tomić-Koludrović, Inga, Zdravković, Željka and Petrić, Mirko (2012). "Changing Identities: Croatian Youth at the Threshold of the EU", in: Hanna Scheck (ed.). Changing Identities in South Eastern Europe. Vienna: Centre for Social Innovation (ZSI), pp. 68-90.

Tomić-Koludrović, Inga, Zdravković, Željka and Skočić, Romana (2011). "Youth Lifestyles and Leisure in a Post-transitional Context", paper presented at the conference 20 years after: problems and prospects of countries of former Yugoslavia, Maribor, Slovenia, 2 December 2011.

Verdery, Katherine (1999). "Fuzzy Property: Rights, Power, and Identity in Transylvania's Decollectivization", in: Michael Burawoy and Katherine Verdery (eds). Uncertain Transition: Ethnographies of Change in the Postsocialist World. Lanham, Md.: Rowman \& Littlefield, pp. 53-82.

Vuković, Slobodan (1990). Radništvo u strukturi jugoslovenskog društva. Doktorska disertacija [Workers in the structure of Yugoslav society. Doctoral dissertation]. Sveučilište u Zagrebu, Filozofski fakultet.

Wacquant, Loïc J. D. (1993). "Bourdieu in America: Notes on the Transatlantic Importation of Social Theory", in: Craig Calhoun, Edward LiPouma and Moishe Postone (eds). Bourdieu: Critical Perspectives. Chicago: Chicago University Press, pp. 263-275.

Woodruff, David (1999). "Barter of the Bankrupt: The Politics of Demonetization in Russia's Federal State”, in: Michael Burawoy and Katherine Verdery (eds). Uncertain Transition: Ethnographies of Change in the Postsocialist World. Lanham, Md.: Rowman \& Littlefield, pp. 83-124. 
Wright, Erik Olin (1997). Class Counts: Comparative Studies in Class Analysis. Cambridge: Cambridge University Press; Paris: Les éditions de la Maison des sciences de l'homme.

Zbierski-Salameh, Slawomira (1999). "Polish Peasants in the "Valley of Transition': Responses to Postsocialist Reforms", in: Michael Burawoy and Katherine Verdery (eds). Uncertain Transition: Ethnographies of Change in the Postsocialist World. Lanham, Md.: Rowman \& Littlefield, pp. 189-222.

Zdravković, Željka (2014). Medijska dimenzija životnih stilova studenata/ica kao pokazatelj razvojnog potencijala regije. Doktorski rad [The media dimension of student lifestyles as an indicator of the regional development potential. Doctoral thesis]. Zadar: University of Zadar.

Županov, Josip (1985 [1969]). Samoupravljanje i društvena moć [Selfmanagement and the social power]. Zagreb: Globus.

\title{
Klasa u jugoslavenskom socijalizmu i u postjugoslavenskim društvima: prema bourdieuovskom repozicioniranju problema (Drugi dio)
}

\author{
Inga TOMIĆ-KOLUDROVIĆ \\ Institut društvenih znanosti Ivo Pilar - Područni centar Split, Hrvatska \\ inga.tomic-koludrovic@pilar.hr \\ Mirko PETRIĆ \\ Odjel za sociologiju, Sveučilište u Zadru, Hrvatska \\ mpetric@unizd.hr
}

Članak pokušava u glavnim crtama prikazati ono što njegova autorica i autor vide kao potencijalno produktivan metodološki pristup proučavanju veze između pojma klase u socijalističkoj Jugoslaviji i razvoja događaja povezanih s klasom u zemljama koje su joj sljednice. Prvi dio teksta sastoji se od dulje rasprave o ideološkim i društveno-teorijskim koncepcijama klase tijekom socijalističkog razdoblja u Jugoslaviji (1945.-1990.). U ovoj se raspravi predlaže interpretacija koja dijagnosticira implicitan i prethodno malo zamijećen interpretativni pomak od Marxova dualnoga prema Weberovu multidimenzionalnom modelu u predempirijskim objašnjenjima klase u jugoslavenskoj društvenoj teoriji. Nakon toga, donosi se prikaz empirijskih istraživanja usredotočenih na klasu iz sedamdesetih i osamdesetih godina 20. stoljeća, koja se kolebaju između marksizma i strukturalnog funkcionalizma te $u$ konačnici teže analitičkom pomirenju pojmova klase i sloja. U drugom dijelu članka, raspravlja se o repozicioniranju problematike u smislu Bourdieuove teorije klase, što se vidi kao mogući doprinos objašnjavanju brojnih slijepih točaka socijalističkog teoretiziranja o klasi. Taj dio članka 
također sadržava sažet komentar istraživanja povezanih s klasom u postjugoslavenskim društvima, odnosno u razdoblju postsocijalističke tranzicije. Pozivajući se na empirijska istraživanja provedena u dvjema postjugoslavenskim zemljama (Srbiji i Hrvatskoj), autorica i autor zaključuju da se Bourdieuova teorija klase, obogaćena križanjem s drugim metodologijama, ponovno pokazuje korisnom $\mathrm{u}$ tom kontekstu i da može poslužiti kao uvjerljiva interpretativna poveznica između socijalističkih i postsocijalističkih društvenih prostora.

Ključne riječi: klasa, jugoslavenski socijalizam, postjugoslavenska društva, Bourdieuova teorija klase, historijska sociologija 